\title{
Erratum to: Assessment of variations in water quality using statistical techniques: a case study of Ișıklı Lake, Çivril/Denizli, Turkey
}

\section{Fatma Aksever $^{1} \cdot$ Seher Büyükșahin ${ }^{1}$}

Published online: 8 April 2017

(C) Saudi Society for Geosciences 2017

Erratum to: Arab J Geosci (2017) 10:143

DOI 10.1007/s12517-017-2877-4

The original version of this paper was published with incorrect

Fig. 5 caption. Given in this article is the correct caption.

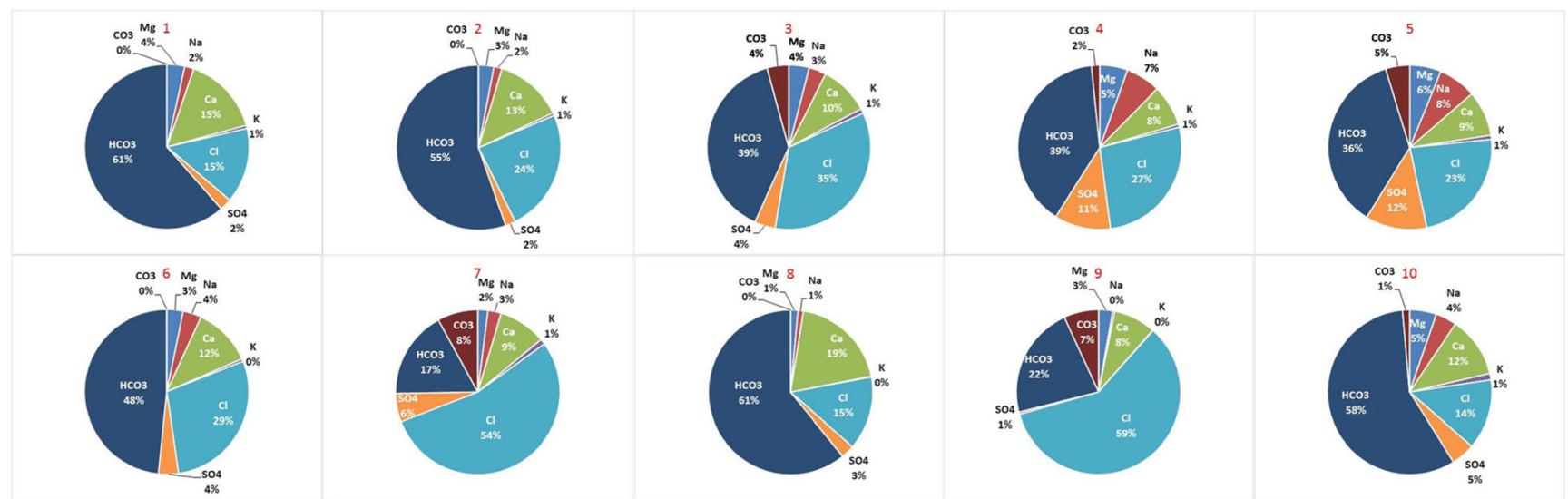

Fig. 5 Pie charts of waters, 1, 2 Dinarsuyu stream, 3 Büyük Menderes River, 4, 5, 6 Kufi stream, 7 Ișıklı spring, 8 Yuva spring, 9 Gümüșsu spring, 10 Ișıklı Lake

The online version of the original article can be found under at http://dx. doi.org/10.1007/s12517-017-2877-4

Fatma Aksever

fatmaaksever@sdu.edu.tr

Seher Büyükşahin

seherbuyuksahin@hotmail.com

1 Department of Geological Engineering, Süleyman Demirel

University, Isparta, Turkey 